transmontana Gosse). One colony was discovered and several specimens collected in the marsh next to the wet meadow where the Harris' Checkerspot was found, the Eyed Brown seeming to prefer a wetter habitat. I took these specimens as I flushed them from the thick grassy cover of the marsh, July 7-9, 1966. This eastern species has also been taken previously as far west as Beulah and Birtle, Manitoba.

LITTLE WOOD SATYR (Euptychia cymela cymela Cramer). Many speci- mens were collected east of Tantallon, July 6-9, 1966. All specimens looked as if they had been on the wing for some time. They were hard to capture as they dodged through the thick hazel-nut bushes that grow around the oak trees. This eastern species has been taken before as far west as Beulah, Manitoba. I have an unauthenticated report of a specimen being taken by a Mr. Shaw in the Weyburn area. This specimen is somewhere in an American collection, and I have not been able to confirm its identity.

\title{
HISTORY OF THE COUGAR IN SASKATCHEWAN
}

\section{by Thomas White, $1-2105$ Cornwall St., Regina}

This article records stories I have collected over the last six years. Only two reports could be verified by hides obtained from the animals, but all were given in good faith by persons who remember the experience as exceptional. The wide distribution and the dates of the reports are interesting. Both the South and North Saskatchewan River valleys are ideal cougar habitat and it is questionable if the cougars that occupied it were wanderers. The cougars of the Pasquia Hills are far from the known cougar range, and it is likely that they have always been native to this area. Other reports may indicate that historically the cougar occurred elsewhere and it has always been an extremely rare native of Saskatchewan.

Historical reports of the cougar in Saskatchewan are of interest because cougars were previously considered to exist in Canada only in the mountains of British Columbia and Alberta, with an occasional wanderer roaming into the Cypress Hills in the southwestern part of Saskatchewan.

The writings of Ernest Thompson Seton (1929) contain no reference to cougars in Saskatchewan though he mentions almost every other province and state in North America. Young and Goldman (1946), whose book on the cougar is the most comprehensive so far published, give one record south of Kindersley and say that reports are extremely rare. The standard works on mammals either exclude the province entirely or put the extreme outer edge of the range in the Cypress Hills, although one has a question mark in the Pasquia Hills. Dewey Soper (1961a) states that there are unconfirmed reports of cougars being killed in the southern part of the province, mainly in the early part of the century when occurrences were rare and becoming rarer, and gives two probable records: in 1912 near old Fort Walsh, Cypress Hills, and in 1939 south of Kindersley as reported by Young and Goldman. Beck (1958) reports a 1948 record for Connell Creek, but states that cougars are occasional stragglers. A recent pamphlet by Victor Cahalane (1964) excludes most of the province, but shows an area in the west of the province above Lloydminster and Battleford where they are described as rare wanderers and probably not residen's, and a question mark in Manitoba west of Lake Winnipeg. Anderson (1946) writes that cougars ranged "east formerly to western Saskatchewan and northwestern North Dakota."

There are records of cougars in all the areas adjacent to Saskatchewan 
luring this century, which indicates hat this general area can not have been alien to them in relatively recent imes. North Dakota, Montana, Manicoba, the Hudson Bay region and Alberta have their records, though with the exception of the latter they were considered rare.

In North Dakota there are historic ceords of cougars by both Maximilian and Theodore Roosevelt during the nineteenth century, but Auduoon did not comment on them during his trip up the Missouri in 1843. In the early part of this century there are numerous reports along the Miscouri and Little Missouri Rivers; Bailey (1926) reported a specimen collected in 1902 about 25 miles east f Williston, though as time went on most naturalists considered it to be extinct in that state. However, a plaster cast of a track was obtained in 1943 near the Missouri River, 50 miles south of the Saskatchewan border below Carnduff.

In the early part of the century both Fountain and Ingersoll wrote that the cougar ranged near to $\mathrm{Hud}$ son Bay. Ernest Thompson Seton recorded a number of cougars reported killed in Manitoba near the Saskatchewan border, the latest being in 1904 . Soper (1961b) reports cougars at the foot of Turtle Mountain between 1921 and 1951, and also at Birtle in 1922 and Marquette in 1942, also in Manitoba. Preble (1908) reports tracks were seen by J. S. Edmonton about 1897 on Boiler Rapid and Grand Rapid on the Athabasca in Alberta.

The Bear Paw mountains of Montana are clearly visible from the Cypress Hills and creeks cross the International Boundary, which make a connection. A cougar was shot there in 1910 and is exhibited in Havre. The Milk River from the foothills of the Rockies connects that known cougar range to the Cypress Hills. An average of 43 cougar bounties per annum were obtained in Alberta up to 1947, though mainly in the mountains.

Bob Wilden of the R.C.M.P. said that a cougar was killed at Fort
Walsh sometime before 1890. Bob Symons remembers Dumont, a relative of Louis Riel's Gabriel Dumont, who lived near Fort Walsh, saying that cougars were occasionally found in the Cypress Hills around the turn of the century.

Glen Meyers was working on a ranch near Empress, just inside the Saskatchewan border, when a cougar was killed in 1904 by M. J. More. The hide soon deteriorated but the tail was indestructible and stiff like a broom handle. It was kicked around for years, becoming a ranch joke, and was still there in 1918 when Glen left the ranch.

In $1906 \mathrm{Mr}$. Carter, the present mayor of Outlook, was berry picking on the South Saskatchewan River when he came up over a bank and looking across the draw saw a cougar in the branch of a tree looking him full in the face. He was familiar with cougars in British Columbia and after watching it for some minutes went to his buggy for his gun, but when he returned the animal was gone.

In December, 1911 Hector McCrae and George Parsonage were hunting for deer in the Cypress Hills near Fort Walsh. They came over a rise and saw a cougar which they shot. They made a bad job of skinning it and only got $\$ 10.00$ from a local rancher, Mr. Massonage, although they could have received more than double that if it had been skinned properly. The skin remained at the ranch until recently. George Parsonage was killed in the trenches of the First World War but Hec, now in his 70 's, claims to be the last man to shoot a cougar in that part of the world. However, when Bob Symons ranched in the Cypress Hills in 1914 he knew Jim McGary, the first Game Warden in the area. Jim had a cougar skin in his log cabin which he had recently shot nearby.

In 1912 Dave Santy hitched up his wagon at Herbert and drove across the prairie to where there was a ferry that would take him across the South Saskatchewan River. This ferry was operated by a Squaw man who also 


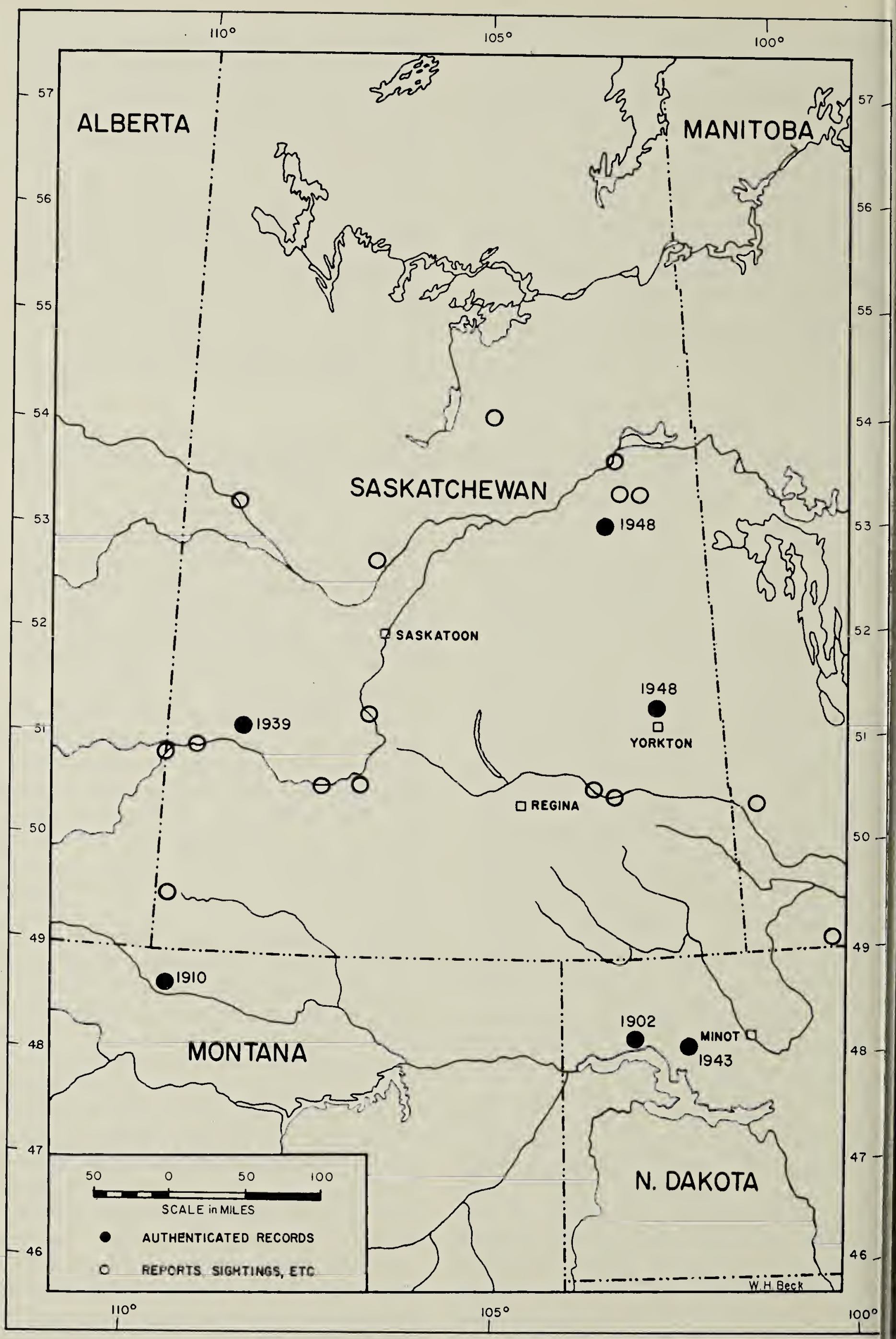

Cougar records and reports for Saskatchewan and surrounding areas. 


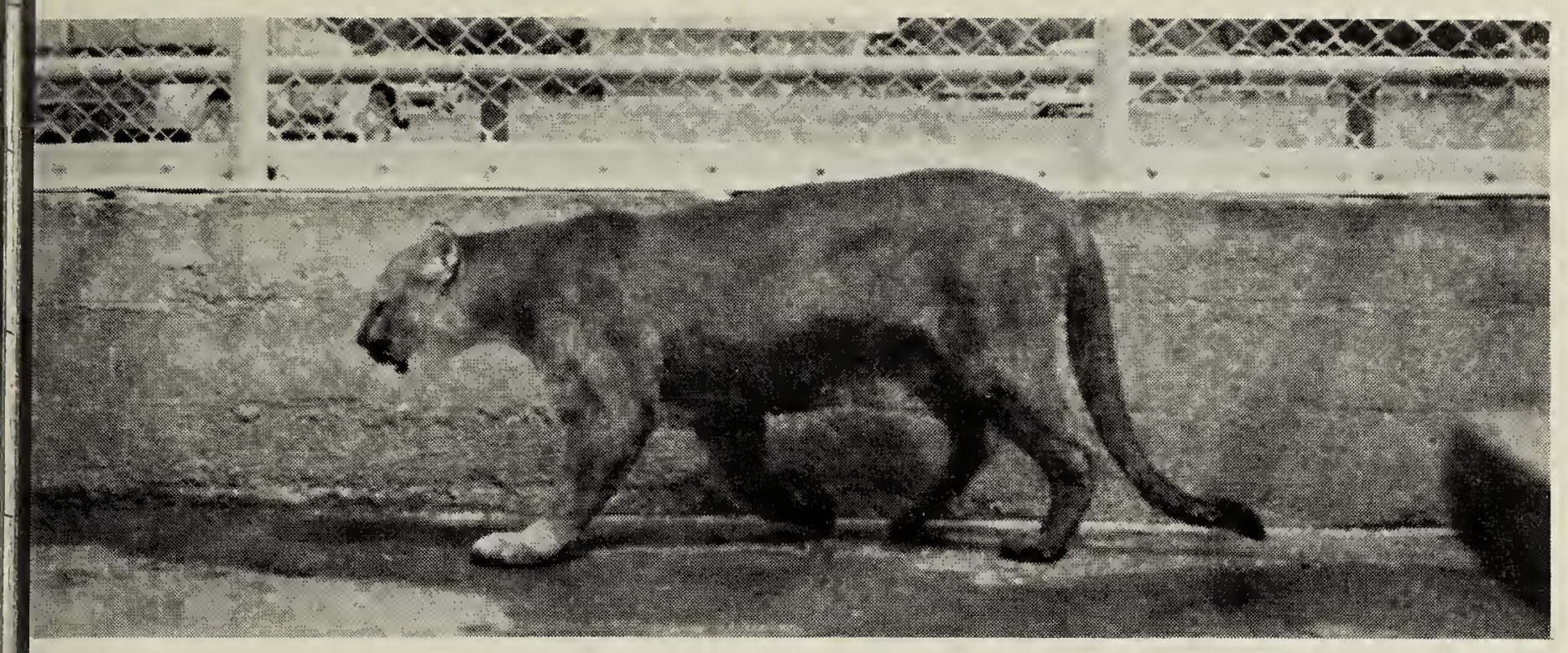

Captive cougar in zoo

Photo by T. White

trapped. Skins around the walls were representative of most of the animals in the general area, and the Squaw man said that he found cougars in the river valley occasionally.

In 1913 Ansgar Aschim, past president of the Saskatchewan Natural History Society and a forester, was riding in a democrat with his father by the South Saskatchewan River north of Herbert. They saw what appeared to be a wolf lying on the top of a hill, so his father dropped off the buggy and circled one way while Ansgar drove on and circled it from the other side. The wolf turned out to be a cougar, and his father shot it between the backbone and stomach. The cougar came towards Ansgar who, helped by his father, shot the animal. The size of the beast was quite frightening and the size of the tail was remarkable. Ansgar also says that there were reports of a cougar shot at Log Valley in 1923.

In 1919 at Blaine Lake there were many reports of a cougar. Mrs. Bould used to ride to her one-roomed country school on horseback, and found herself being followed by a large cat with a long tail which frightened the horse. It followed her, being occasionally seen as it passed between clumps of bushes. One evening the cattle panicked and the damnedest yells were heard in the neighborhood. The cougar was shot by a homesteader who was known as not being the most reliable of story tellers, so Mrs. Bould's parents laughingly demanded the proof. They were sent the paw, which was over four inches in diameter, unfurred on the underside and just like a great domestic cat's. People came from fiar and wide to see the dead cougar though in their area the lynx was well known. Several years ago a house was pulled down and in the studding was found a newspaper which showed a photo of the dead cougar. Mr. Fuchs, who owns the wildlife exhibit in Lloydminster and is a lifetime trapper, remembers the cougar killed at Blaine Lake and that it was a large tom. He also remembers that in 1911 he was hunting along the North Saskatchewan, 20 miles south of St. Walburg, when he came face to face with a cougar in a clearing in the bush at a 25-yard distance. At that time a number of colts had been killed nearby and there was talk of a cougar being around. Mrs. Bould was picnicking on the banks of the North Saskatchewan in 1921 with a friend from the Rockies who was familiar with cougars. There was a spine-chilling cry, which the friend said was undoubtedy that of a cougar.

In 1928 on a farm on the South Saskatchewan north of Leader, Glen Meyers heard his dogs barking wildly and so took his shotgun and went down near the river where a hen enclosure was built into the bank. He found that the dogs had put a cougar 
up on to a rise. It was standing with its long tail moving from side to side and snarling back at the dogs. Glen put two shotgun shells into the animal at 20 yards, and kept the skin for a number of years until a trapper who used to work the South Saskatchewan River bought it from him. The animal was thin and its belly was lighter than its top coat.

Mr. Kemp of the Hudson's Bay Company was fur trading in the Churchill River area between 1921 and 1929. At this time some of his most reliable Indians reported coming upon cougars periodically. The Hudson's Bay Company Archives indicate that in 1929 a cougar hide was traded to the Company in the northern half of the province, the exact location of which cannot be determined.

Joe Langlois was in the Qu'Appelle Valley north of Sintaluta when he came upon a cougar about 1929 . He pursued it with a friend on horseback with two dogs. When they caught up to the cougar it turned and snarled and the dogs turned tail, whining, and Joe did not venture any nearer.

Fred Preece was trapping in the eastern Pasquia Hills around 1935 when he came upon large, deep cat tracks five inches in diameter. He was familiar with both lynx and wolf but these tracks were quite different and he is sure they were cougar tracks.

In $1937 \mathrm{Al}$ Smith was driving a Model A Ford five miles west of Fort Walsh when he came upon a cougar on the road, accelerated and got quite near, obtaining a clear view before the cougar left the road. In the 1940's he saw a cougar in the field by War Bonnet Hill near Fort Walsh.

In 1939 near Madison, south of Kindersley, Harry Wahlgemuth was up in the early morning and saw a cougar circling the cattle pens. He got his rifle and shot it. The skin was obtained and reported by Clarke (1942). This record is included in Young and Goldman and is one of the two records where the skin was preserved and was recorded by a naturalist.
In 1940 Stanley Holloway was employed by the Department of Natural Resources, putting out forest fires in the country near the present site of the Squaw Rapids Dam. After putting out the fire, Stanley left the most elderly fire fighter to stamp out the last remaining ashes and came back to pick him up some days later. He came over the top of the hill in his truck and saw a cougar on the road. Stanley, who is President of the Nipawin Fish and Game League, is a crack shot and carried his rifle in the truck. He got a shot away just as the animal leaped from the road. He did not think he had hit it, but he went to examine the place where the cougar had been, saw a spot of blood, and found the animal dead at the bottom of the bank. It was a cougar, with its distinctive long tail, but because there was no bounty involved the skin was not taken. Stanley says that in the Pasquia Hills area in the period between the wars there were all kinds of trophies obtained, but they were not kept, though a number of his friends always said there was the odd cougar around. In 1923 Stanley lived in the Pasquia Hills and knew the cries of the wolf and lynx. Over a period of time they heard spinechilling cries quite near their cabin which they could not recognize but subsequently believed were those of cougar.

In the 1930's Charlie Otterbein was a forester in the northern part of the Pasquia Hills and found no sign of cougar until the winter of 1938. Prior to this the local Indians had started talking of cougars but little belief was placed in their stories. In the winter of 1938 Charlie was walking along the ice of the Man River when he heard caterwauling and cries of a pair of cougars. He could not catch up with them but their tracks could be seen plainly upon the snow on top of the ice where they had been leaping along. Subsequent to this, he frequently came across cougar tracks in the western part of the Pasquia Hills, particularly around Cracking River. Charlie says that in 1940 some hunters 
brought in a dead cougar and had to pass the gatekeeper of The Pas Lumber Company, a man who had the reputation of being a reliable observer, and who described the long distinctive tail.

About 1942 Wilfred Rainville was walking through a stubble field near the edge of the Qu'Appelle Valley north of Wolseley. It was early morning and when he was nearing the edge of the field a cougar rose out of the stubble and stood looking at him. After a minute it loped away towards a coulee where some rye was uncut, and when it got to the other side of the rye it stood up on its hind legs and looked back before disappearing. Mr. Rainville stepped out 40 steps as the distance from which he first sighted the animal and found the stubble was crushed where it had been lying. Mr. Rainville says it was unquestionably a cougar.

Jim Cloutier came from Rocky Mountain House to the eastern Pasquia Hills in the late 1940's. Jim was familiar with cougar from the Rockies and came across some deer carcasses which had been skinned out the way that cougars kill, but at that time did not think there were cougars in the area.

In 1948 there were reports of a cougar north of Yorkton and, acting upon this information, the R.C.M.P. made an investigation and obtained a plaster cast of its track which was subsequently authenticated.

During the winter of 1948 Carl Heaney was trapping in the Wapaweka Hills near Little Bear Lake. His dog sled was moving over the snow when the dogs began frenzied barking and became very wild. He found large, round cat tracks which were deep and distinct and not those of the lynx, which he had trapped and was familiar with. The dogs increased their speed and after some distance they caught sight of a cougar which managed to outdistance them by going in a different direction.

The winter of 1948 Joe Fournier, a trapper who obtained many of the specimens in the Saskatchewan
Museum of Natural History and who is noted by naturalists who have worked with him as a highly observant and accurate fieldman, was moving along his trap line near Connell Creek in the Pasquia Hills with a horse and ski buggy when he noted that a kind of wolf was following him, but it did not walk in the way wolves normally do. He set a wolf trap and when he came to inspect it a week later he found the green eyes of a cougar looking at him. He killed it with one shot of a .22 and then brought it to Regina where it is exhibited in the Saskatchewan Museum of Natural History. Joe says that when the animal was in the trap another cougar had visited it, and that in the following years he has come across other cougar tracks as well as deer killed by cougars.

From 1948 onwards, the records of people who claim to have seen cougars are much more numerous and widespread, and the impression of the writer is that the turning point in the cougar status was in the late 1940's, and that at this time it changed from being an extremely rare animal and began expanding its range. When Joe Fournier saw that another cougar had visited the one he had trapped, the resurgence of the cougar was ander way in Saskatchewan.

\section{LITERATURE CITED}

Anderson, R. M. 1946. Catalogue of Canadian recent mammals. Bull. Nat. Mus. Canada, 102.

Bailey, V. 1926. A biological survey of North Dakota. N. Amer. Fauna, 49.

Beck, W. H. 1958. A guide to Saskatchewan mammals. Spec. Publ. 1, Sask. Nat. Hist. Soc.

Cahalane, V. H. 1964. A preliminary study of distribution and number of cougar, grizzly and wolf in North America. New York Zoological Soc., New York.

Clarke, C. H. D. 1942. Cougar in Saskatchewan. Can. Field-Nat., 56 (3) : 45.

Preble, E. A. 1908. A biological investigation of the Athabasca-Mackenzie region. N. Amer. Fauna, 27.

Seton, E. T. 1929. Lives of game animals ... 2. Doubleday \& Co., Inc., Garden City, N.Y.

Soper, J. D. 1961a. Field data on the mammals of southern Saskatchewan. Can. Field-Nat., $75(1): 23-41$.

1961b. The mammals of Manitoba. Wildlife Mgt. Bull., Can. Wildlife Service, ser. 1, no. 17.

Young, S. P. and E. A. Goldman. 1946. The puma, mysterious American cat. Amer. Wildlife Inst. 